\title{
DEFENSIVE ADAPTATIONS IN OPISTHOBRANCHS
}

\author{
By T. E. Thompson \\ Marine Biological Station, Port Erin, Isle of Man*
}

(Text-fig. I)

This is the third and concluding part of an investigation into defensive mechanisms in some British gastropods. The first part (Thompson \& Slinn, I959) dealt with a single species of opisthobranch, Pleurobranchus membranaceus, which proved able to secrete a strong acid if disturbed. The second part (Thompson, I960 a) recorded further instances of acid secretion. The present paper describes the remainder of my work on opisthobranchs.

The two earlier studies were rendered more easy to interpret by the relatively simple nature of the defensive fluid; in the forms to be dealt with herein it has not been possible to attempt any biochemical investigations in view of the complexity and diversity of the materials involved.

Observations on defensive adaptations in opisthobranchs were made by Garstang (I889, I890a), by Herdman \& Clubb (I892), by Crossland (I9II) and by Crozier (1917). Cott (1940), in Adaptive Coloration in Animals, summarizes the work of Garstang and Crossland, but omits any reference in the text to that of Crozier or of Herdman \& Clubb. It is unfortunate that Cott's account is marred by some misconceptions regarding opisthobranchs; for instance, after mentioning the batteries of nematocysts possessed by some nudibranchs, he states (p. 254) in a section entitled 'Poison in defence': 'So effective are these batteries as a deterrent, that fishes have been known to eat shelled molluscs such as Margaritifera which had been long pickled in formalin, in preference to fresh specimens of the Nudibranch Chromodoris.' Chromodorid nudibranchs do not possess nematocysts. Similarly, in a section entitled 'Warning coloration in other groups of animals', Cott mentions Garstang's (1890a) work as follows: 'Certain species in the suborder [Tectibranchia], such as Scaphander lignarius, Haminoea hydatis, and Philine aperta, are largely preyed upon by fishes and are inconspicuously coloured. On the other hand, the related Oscanius membranaceus, a form rendered highly distasteful by defensive acid secretions, "is not eaten by fishes, and is handsomely coloured with red-brown and yellowish markings"' (Cott, 1940, p. 270). It has already been pointed out (Thompson \& Slinn, 1959) that Pleurobranchus (= Oscanius) membranaceus does not exhibit warning coloration; that Philine

\footnotetext{
* Present address: Zoology Department, University College, Cardiff.
} 
can secrete a fluid of the same acidity (approximately $\mathrm{pH}$ - - see Thompson, I $960 \mathrm{a}$ ) as that of Pleurobranchus; and, furthermore, I know of no evidence that Scaphander, Philine and Haminoea are 'largely preyed upon' by fish (see the discussion to the present paper). Cott's arguments here are based on faulty knowledge of the opisthobranchs concerned.

It was clear that a re-investigation of the subject of defence in opisthobranchs was necessary; to this end, I have made observations on as wide a variety of forms as possible, attempting to relate the morphology and natural history of the mollusc to data resulting from aquarium experiments with fish.

The nomenclature and classification of British animals mentioned herein are those advocated by the Port Erin Fauna list (to be published). In the case of foreign species, the name employed is that used by the author cited.

\section{METHODS}

Material for sectioning was fixed in the fluids of Zenker (with or without acetic acid), Helly, Perényi, Bouin, Lewitsky (with added sodium chloride) or Ciaccio. Of these, the last two gave by far the best results. The embedding medium used was Hance's rubber wax (Gurr) and sections were cut at from 4 to ro $\mu$. Stains employed included the azan and the alum haematoxylin of Heidenhain, safranin and light green, Mayer's haemalum, eosin and alcian blue 8 GS (Steedman, 1950). Preparations stained intravitally with neutral red were useful.

In the feeding-acceptability experiments, the procedure and the species of fish used were exactly as described in an earlier paper (Thompson, I960a). These experiments were carried out in the Port Erin Aquarium. Each species of opisthobranch was tested at least twelve times; with the more readily obtainable species of nudibranch, the number of tests made was nearer thirty. Because of the difference in size between the various species of opisthobranchs, the fish to which any individual mollusc was offered was selected partly on the grounds of its size; there would have been little point, for instance, in offering the tiny Elysia or Doto to a large cod, for such fish often ignore very small objects. Particular care was taken always to ensure that the opisthobranchs tested were not damaged or otherwise enfeebled, for experience showed that resistance to enemies falls if vitality is low.

To test the taste of various opisthobranchs to the human palate, the specimens were first rubbed between the fingers in order to initiate any defensive reaction, and then placed in the mouth; the reactions of the observer were recorded. The results of these tests were not uniformly reliable for difficulty was experienced in separating the saline taste of the medium from the taste of any defensive secretion; it is probable that the human tongue fails to detect some of these secretions, especially in the case of the smallest molluscs. The tests were carried out by the author and $\mathrm{Mr} \mathrm{D}$. Eggleston. 


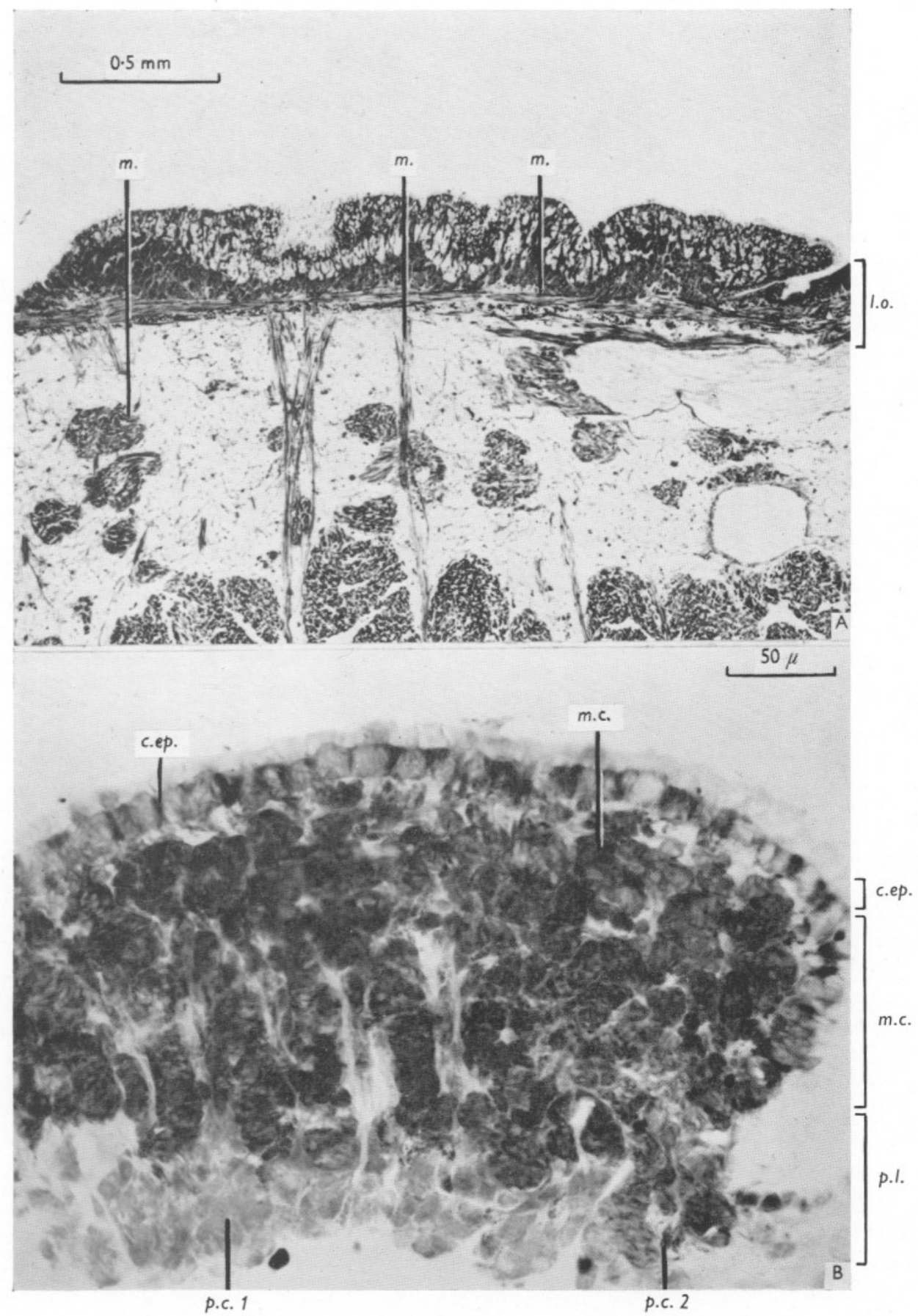

(Facing p. I I4) 
The acidity of the skin secretions was estimated by means of B.D.H. pH papers.

\section{Feeding-acceptability tests}

\section{RESULTS}

The results of the aquarium tests were rather uniform. No healthy opisthobranch (with a solitary exception) was ever seen to be ingested by any of the fish used. The exception was a single Hero formosa which was eaten by an Acanthocottus, while other individuals were invariably rejected. Dead or severely damaged opisthobranchs were, however, usually taken readily. The fish usually inspected the test organism closely (the manner of inspection varying with the species of fish); on some occasions a healthy opisthobranch was taken into the mouth but rejection almost invariably followed. In a large tank containing a number of excited hungry fish, a mollusc may be 'tasted' by every individual present before it reaches the bottom. The test organisms were seldom damaged in the process of tasting and rejection. There is no point in giving here any details concerning the behaviour of the fish used in these experiments, since Bateson (1890) describes particularly fully the reactions of various species of fish to test foods.

\section{Further observations}

In Table I, data concerning the histology of the skin, natural history and defensive behaviour are listed for the species of opisthobranchs investigated. These data are derived mainly from the present investigation. For each species reference is made to a work in which appears a good illustration; in this way lengthy descriptions of the external features have been avoided. Epidermal mucous glands have been ignored; wherever the term gland is used alone, it may be taken to mean non-mucous gland.

\section{DISCUSSION OF LITERATURE}

Records of the predation of fish on bottom-living opisthobranchs are few. Of the species listed in Table I, only Tritonia hombergi, Scaphander lignarius and Philine quadripartita have been found to be eaten by fish in nature. The jaws of Tritonia hombergi have been found occasionally by the author in the stomachs of dogfish (Scyliorhinus canicula) dissected by students at University College, Bangor; Ford (I92I) found Scaphander lignarius in the stomachs of two dogfish of this same species; Todd (1903) found Philine quadripartita in the stomachs of a very few fish. Aeolidia papillosa (a British nudibranch not dealt with in the present study) was recorded by Homans \& Needler (I944) from the stomachs of young haddock (Melanogrammus aeglefinus). Akera bullata has been found (Lemche, 1929) in the stomach of Limanda limanda. 
TABLE 1. SUMMARY OF WORK ON DEFENSIVE

\begin{tabular}{|c|c|c|c|c|c|c|}
\hline $\begin{array}{c}\text { (I) } \\
\text { Species }\end{array}$ & $\begin{array}{c}\text { (2) } \\
\text { Source } \\
\text { of } \\
\text { data }\end{array}$ & $\begin{array}{l}\text { (3) } \\
\text { Reference } \\
\text { to good } \\
\text { illustration }\end{array}$ & $\begin{array}{l}\text { (4) } \\
\mathrm{pH} \text { of } \\
\text { skin } \\
\text { secretion }\end{array}$ & $\begin{array}{l}\text { (5) } \\
\text { Taste } \\
\text { to } \\
\text { tongue }\end{array}$ & $\begin{array}{l}\text { (6) } \\
\text { Tests } \\
\text { on } \\
\text { fish }\end{array}$ & $\begin{array}{l}\text { (7) } \\
\text { Cnido- } \\
\text { sacs }\end{array}$ \\
\hline Aplysia punctata & $P$ & $\begin{array}{l}\text { Eales, r921; } \\
\text { Wilson, r937 }\end{array}$ & $\mathrm{N}$ & Bitter $†$ & $\mathrm{X}$ & Abs. \\
\hline Scaphander lignarius & $\mathbf{P}$ & P.-F., p. 57 & $\mathrm{~N}$ & Bitter & $\mathrm{x}$ & Abs. \\
\hline Philine quadripartita & $T(2)$ & P.-F., p. 65 & ca. I & Bitter-Sour & $\mathrm{X}$ & Abs. \\
\hline Berthella plumula & $T(2)$ & B.Y., Pl. I8 & ca. $\mathbf{I}$ & Bitter-Sour & $\mathrm{X}$ & Abs. \\
\hline $\begin{array}{l}\text { Pleurobranchus mem- } \\
\text { branaceus }\end{array}$ & T.S. & T.S. & ca. I & Bitter-Sour & $\mathrm{x}$ & Abs. \\
\hline Hermea dendritica & $P, G$ & A.H., 3, pl. 40 & - & 一 & 一 & Abs. \\
\hline Elysia viridis & $\mathbf{P}$ & Eliot, pl. VII & $\mathrm{N}$ & $\mathrm{O}$ & $\mathrm{X}$ & Abs. \\
\hline Duvaucelia plebeia & $\mathbf{P}$ & A.H., 2, pl. 3 & $\mathrm{~N}$ & - & - & Abs. \\
\hline Tritonia hombergi & $\mathbf{P}$ & A.H., 2, pl. 2 & $\mathrm{~N}$ & Bitter $\ddagger$ & $\mathrm{X}$ & Abs. \\
\hline Dendronotus frondosus & $\mathbf{P}$ & A.H., 3, pl. 3 & $\mathrm{~N}$ & $\mathrm{O}$ & $\mathrm{X}$ & Abs. \\
\hline Doto coronata & $\mathbf{P}$ & A.H., 3, pl. 6 & $\mathrm{~N}$ & $\mathrm{O}$ & 一 & Abs. \\
\hline Hero formosa & $\mathbf{P}$ & Eliot, pl. IV & $\mathrm{N}$ & $\mathrm{O}$ & $*$ & - \\
\hline Eubranchus tricolor & $\mathrm{P}$ & A.H., 3, pl. 34 & $\mathrm{~N}$ & $\mathrm{O}$ & $\mathrm{x}$ & Pres. \\
\hline Facelina auriculata & $\mathbf{P}$ & A.H., 3, pl. 12, I3 & $\mathrm{N}$ & O & $\mathrm{x}$ & Pres. \\
\hline Archidoris pseudoargus & $\mathbf{P}$ & A.H., I, pl. 3 & $\mathrm{~N}$ & $\mathrm{O}$ & $\mathrm{x}$ & Abs. \\
\hline forunna tomentosa & $\mathbf{P}$ & A.H., r, pl. 5 & $\mathrm{~N}$ & $\mathrm{O}$ & $\mathrm{x}$ & Abs. \\
\hline Acanthodoris pilosa & $\mathbf{P}$ & A.H., I, pl. I5 & $\mathrm{N}$ & $\mathrm{O}$ & $\mathrm{x}$ & Abs. \\
\hline Onchidoris pusilla & $\mathbf{P}$ & A.H., r, pl. I3 & $\mathrm{N}$ & $\mathrm{O}$ & - & Abs. \\
\hline O. fusca & $\mathbf{P}$ & A.H., I, pl. II & $\mathrm{N}$ & $\mathrm{O}$ & $\mathrm{x}$ & Abs. \\
\hline O. muricata & $\mathbf{P}$ & A.H., 1, pl. 9 & $\mathrm{~N}$ & $\mathrm{O}$ & $\mathrm{X}$ & Abs. \\
\hline Adalaria proxima & $\mathrm{T}(\mathrm{I})$ & A.H., r, pl. 9 & $\mathrm{~N}$ & $\mathrm{O}$ & 一 & Abs. \\
\hline Goniodoris nodosa & $\mathbf{P}$ & A.H., I, pl. I8 & $\mathrm{N}$ & O & $\mathrm{x}$ & Abs. \\
\hline Polycera quadrilineata & $\mathbf{P}$ & A.H., I, pl. 22 & $\mathrm{~N}$ & $\mathrm{O}$ & $\mathrm{x}$ & Abs. \\
\hline $\begin{array}{l}\text { Ancula cristata } \\
\qquad \begin{array}{c}\text { Notes } \\
\text { Columr } \\
\text { Column } \\
\text { 1958; T } \\
\text { I890a; H } \\
\text { Column } \\
\text { Hancock, } \\
\text { r9ro (sup } \\
\text { Columr } \\
\text { Column } \\
\text { Column } \\
\text { thocottus } b \\
\text { Column } \\
\dagger \text { Both } \\
\text { † Byne }\end{array}\end{array}$ & $\begin{array}{l}\text { H.C. } \\
\text { name of } \\
\text { refers to } \\
\text { Thompso } \\
\text { Herdman } \\
\text { referenc } \\
-55, \mathrm{Far} \\
\text { ent to Al } \\
\mathrm{N} \text {, neut } \\
\text { taste to } \\
\text { acceptab } \\
\text { is, others } \\
\text { cnidosac } \\
\text { le secret }\end{array}$ & $\begin{array}{l}\text { A.H., r, pl. } 25 \\
\text { species as in Port Eri } \\
\text { he following sources } \\
\text { r r } 960 \text {; T.S., Tho } \\
\text { \& Clubb, r892. } \\
\text { s include: B.Y., Bar } \\
\text { ilies I, 2, or 3, as ind } \\
\text { er \& Hancock); T.S., } \\
\text { al. } \\
\text { uman tongue: O, No } \\
\text { lity to fish in tests: X } \\
\text { rejected. } \\
\text { present (Pres.) or at } \\
\text { on and body. } \\
\text { hat this secretion ma }\end{array}$ & $\begin{array}{l}\text { Marine Fa } \\
\text { P, present } \\
\text { pson \& S } \\
\text { ett \& Yon } \\
\text { cated; P.-F } \\
\text { Thompson } \\
\text { e. } \\
\text { always refu } \\
\text { ent (Abs.). }\end{array}$ & $\begin{array}{l}\text { MS. } \\
\text { icle; T (r), Th } \\
\text {, r959; G, C } \\
\text { r958; A.H., } \\
\text { ruvot-Fol, r9s } \\
\text { Slinn, r959. } \\
\text {; * one eaten t } \\
\text { hands. }\end{array}$ & $\begin{array}{l}\text { tang, } \\
\text { er \& } \\
\text { Eliot, } \\
\text { lcan- }\end{array}$ & Abs. \\
\hline
\end{tabular}




\section{ADAPTATIONS IN OPISTHOBRANCHS}

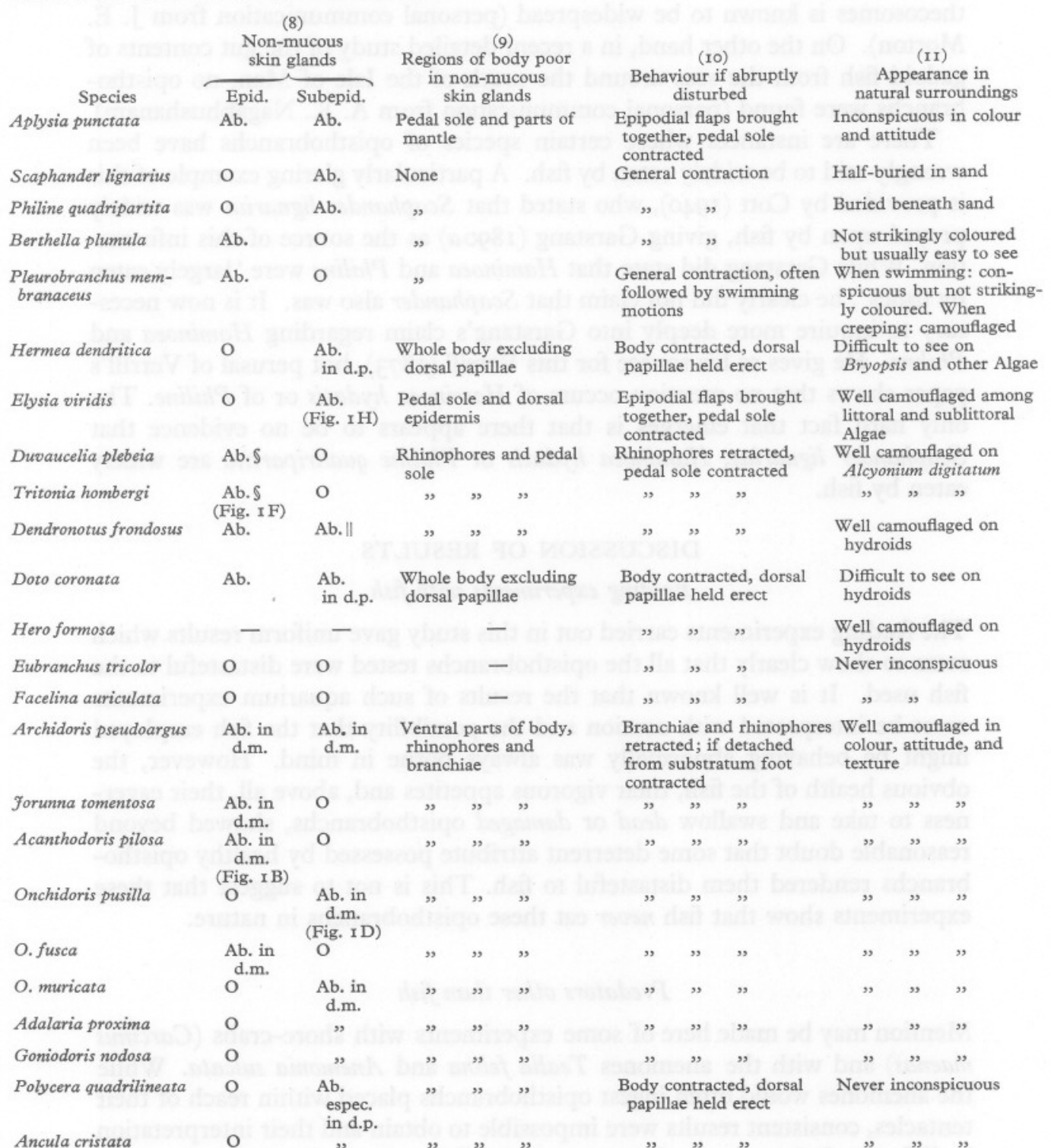

Column (8), non-mucous skin glands may be epidermal (epid.) or subepidermal (subepid.): Ab., abundant; O, not present; d.p., dorsal papillae; d.m., dorsal mantle; espec., especially.

$\checkmark$ Glands of two types in these two species.

II Subepidermal glands occur in adults, especially in the dorsal papillae (see Thompson, $1960 b$ ). 
In addition, predation by various carnivores on pelagic gymnosomes and thecosomes is known to be widespread (personal communication from J. E. Morton). On the other hand, in a recent detailed study of the gut contents of gadoid fish from the seas around the south of the Isle of Man, no opisthobranchs were found (personal communication from A. K. Nagabhushanam).

There are instances where certain species of opisthobranchs have been wrongly said to be widely eaten by fish. A particularly glaring example of this is provided by Cott (1940), who stated that Scaphander lignarius was widely preyed upon by fish, giving Garstang (I890a) as the source of this information. While Garstang did state that Haminoea and Philine were 'largely eaten by fishes', he clearly did not claim that Scaphander also was. It is now necessary to inquire more deeply into Garstang's claim regarding Haminoea and Philine. He gives as his source for this Verrill (1873), but perusal of Verrill's paper shows that no mention occurs of Haminoea hydatis or of Philine. The only hard fact that emerges is that there appears to be no evidence that Scaphander lignarius, Haminoea hydatis or Philine quadripartita are widely eaten by fish.

\section{DISCUSSION OF RESULTS}

\section{Feeding experiments with fish}

The feeding experiments carried out in this study gave uniform results which seem to show clearly that all the opisthobranchs tested were distasteful to the fish used. It is well known that the results of such aquarium experiments must be interpreted with caution and the possibility that the fish employed might be behaving abnormally was always borne in mind. However, the obvious health of the fish, their vigorous appetites and, above all, their eagerness to take and swallow dead or damaged opisthobranchs, showed beyond reasonable doubt that some deterrent attribute possessed by healthy opisthobranchs rendered them distasteful to fish. This is not to suggest that these experiments show that fish never eat these opisthobranchs in nature.

\section{Predators other than fish}

Mention may be made here of some experiments with shore-crabs (Carcinus maenas) and with the anemones Tealia felina and Anemonia sulcata. While the anemones would often ingest opisthobranchs placed within reach of their tentacles, consistent results were impossible to obtain and their interpretation is difficult. It has already been recorded (Thompson, I960a) that Berthella and Pleurobranchus were usually refused by Tealia; it has now been found that the eolidaceans Facelina and Eubranchus also enjoy some kind of immunity from this anemone and others. McMillan (I94I) records similar results. All the other opisthobranchs tested were, however, seen to be ingested by anemones on various occasions, but never predictably. The significance of 
these results hinges on whether this predation occurs in nature; unfortunately, I can offer only the negative information that I have never seen it happen.

Tests with shore-crabs were also unsatisfactory, but more uniform; the crabs always ignored the test organisms.

\section{Nematocysts}

\section{Defensive attributes}

That eolidacean nudibranchs possess cnidosacs at the tips of their dorsal papillae has been known for many years. There can be little doubt that these nematocysts discourage fish from ingesting these molluses, for Cott (I940) mentions that cnidarian tissues are highly distasteful to a variety of fish; my experiments confirm this. That some have been known to be devoured by fish(Homans \& Needler, I944) is not a convincing argument against the theory that one of the functions of the eolidacean cnidosacs is to deter predatory fish.

\section{Acid secretions}

Three species of opisthobranch (and two of prosobranch) gastropods are known to possess the ability to secrete a strong acid through the skin if they are roughly disturbed (Thompson, I960 a). Because Bateson (I890) found fish to refuse any food which had been soaked in dilute acids it is believed that these acid-secreting gastropods are generally refused as food by fish in nature. This is supported by aquarium and other observations.

\section{Other secretions (see Fig. I)}

In all the other opisthobranchs which have been studied in this investigation (see Table I), skin glands have been found whose position and function can only be explained satisfactorily as defensive. They are always present in addition to the usual mucous glands associated with ciliated epithelia. They are always present in greatest abundance in the areas of the skin which would be first encountered by an inquisitive fish in nature. In species which possess dorsal papillae projecting some way out from the body, these glands are always concentrated in the papillae. Papillae of this kind are usually nonretractile, and may be rapidly regenerated if damaged. On the other hand, those dorsal processes which do not contain these glands (such as the rhinophoreal tentacles or the anal branchiae of some nudibranchs) are always retractile and are quickly concealed if the animal is disturbed. The behaviour of the opisthobranch if molested roughly is always such as to bring about the concealment of those regions of the body which are not endowed with these glands.

Histologically these defensive glands exhibit considerable diversity; they may be epidermal or subepidermal, unicellular or multicellular; their secretion may consist of fluids alone or may contain hyaline concretions; the secretion 

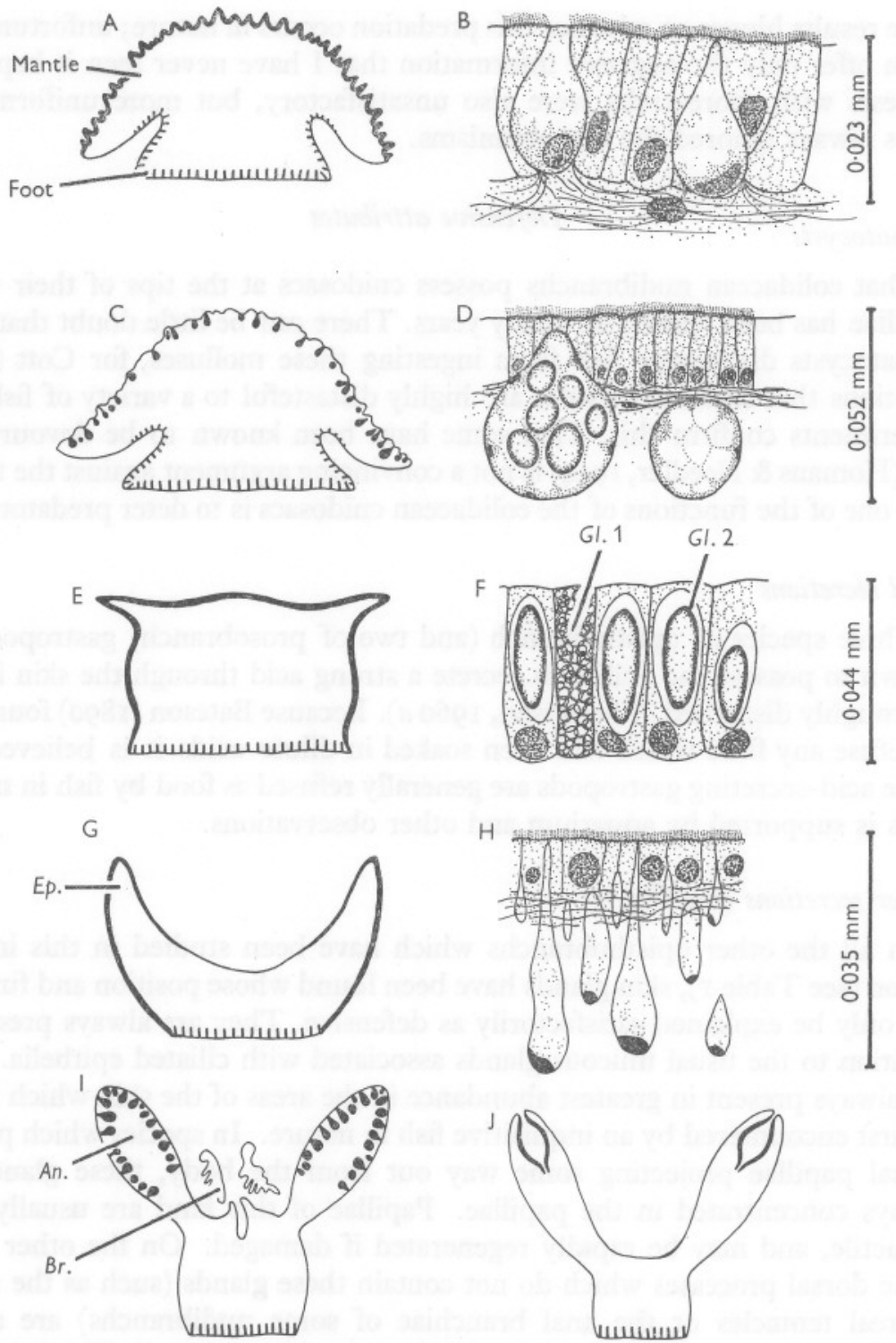

Fig. I. Illustrating the structure and distribution of defensive glands in some representative opisthobranchs. In the diagrammatic transverse sections areas provided with defensive attributes are shown black while areas rich only in mucous glands are hatched. A, diagrammatic transverse section through Acanthodoris pilosa; B, portion of the dorsal integument of A. pilosa at greater magnification; C, diagrammatic transverse section through Onchidoris pusilla; $\mathrm{D}$, portion of the dorsal integument of $O$. pusilla at greater magnification; $\mathrm{E}$, diagrammatic transverse section through Tritonia hombergi; F, portion of the dorsal integument of $T$. hombergi at greater magnification; $\mathrm{G}$, diagrammatic transverse section through Elysia viridis; $\mathrm{H}$, portion of the epithelium of the epipodial flaps of $E$. viridis at greater magnification; I, diagrammatic transverse section through Polycera quadrilineata, passing through the level of the anus; J, diagrammatic transverse section through Facelina auriculata, passing through a pair of cerata and showing the position of the cnidosacs. $A n$., anal tubercle; $B r$, anal branchia; Ep., epipodial flap; $G l$. I, gland of type I; $G l$. 2, gland of type 2 . 
may or may not taste bitter to the human tongue. More than one type of gland may be present in a single species.

The mucus which is secreted profusely if an opisthobranch is roughly handled may decrease the animal's attractiveness as food; this mucus may even aid the effectiveness of the defensive secretions by hindering their toorapid dispersal.

\section{Spicules}

All the dorid nudibranchs have abundant small papillae and calcareous spicules in the skin and it is probable that the spiculose texture of the mantle, while perhaps not of positive deterrent value, would diminish their attractiveness as food to a fish. It is interesting to note that sponges may be refused as food by fish in experiments (Garstang, $1890 b$ ).

\section{Behaviour}

The opisthobranchs studied may be classed as follows, on the basis of their behaviour both in undisturbed conditions and when abruptly disturbed:

(i) Opisthobranchs which, for most of their lives at least, behave in a way which indicates an apparent desire for concealment; this concealment may be achieved by means of coloration, attitude, texture, habitat selection, or a combination of any or all of these.

(a) Forms which, if abruptly disturbed, respond merely by a general contraction of the body, e.g. Scaphander, Berthella, Philine, Pleurobranchus (which may subsequently attempt to swim away). In all these forms the defensive glands are distributed over the whole naked surface of the body.

(b) Forms which, if abruptly disturbed, retract or otherwise conceal parts of the body which are not liberally endowed with skin glands, thus presenting a would-be predator only with those parts which are provided with defensive attributes, e.g. Dendronotus, Doto, Aplysia, Elysia, Hermaea, dorid and tritoniid nudibranchs.

(ii) Opisthobranchs whose behaviour is always characterized by an apparent disregard for concealment. They invariably possess well-developed dorsal papillae and, if an individual is abruptly disturbed, these papillae are held erect while the rest of the body, which is always provided to a lesser extent with any defensive attributes, is contracted, e.g. Ancula, Polycera, Eubranchus, Facelina.

\section{Coloration}

Opisthobranchs which would, on the grounds of their behaviour, fall into class (i) above are always difficult to detect (at least to the human eye) in their natural surroundings. This resemblance or camouflaging is usually achieved by a combination of the coloration of the body and of such dorsal processes as 
may be present, the slow-moving habits, the texture of the body and the selection of a suitable habitat (many nudibranchs are found in narrow crevices, under stones, etc., while Scaphander and Philine lie partly or wholly covered by sand).

Those opisthobranchs which fall into class (ii) above were always brightly coloured, the pigmented areas often being confined to the dorsal papillae. Since I have no evidence that any of the fish employed in my tests 'learned' to avoid any species of opisthobranch, it is best that the terms 'warning' or 'aposematic' coloration be avoided here; nonetheless there is no doubt that the colours, behaviour and form of Ancula, Polycera and the eolids investigated render these animals readily visible to the human eye both in aquaria and in the field. The inference is that they are similarly obvious to fish.

An important point which emerges from a consideration of opisthobranchs in their natural surroundings is that the usual dividing line between brightly coloured, distasteful forms on the one hand, and cryptically marked, readily edible forms on the other, does not hold. In my experiments, no facts emerged which might support a theory that the conspicuous forms (such as Polycera or Eubranchus) were any more or any less acceptable to fish than the cryptically coloured species (such as Aplysia or Archidoris). All the opisthobranchs studied were distasteful to fish. The phenomenon is not new; Cott (I940) mentions that there are a number of species of poisonous snakes which are cryptically coloured. Cott dismisses the idea that this apparent anomaly points to some deep-rooted weakness in the theory of adaptive coloration in animals in the following words (with which I am in complete agreement): '...there is nothing irreconcilable in the fact that some well-defended forms rely upon concealment as a first line of defence. . . while others gain an advantage by being recognized through their conspicuousness as easily as possible' (Cott, 1940, p. 155). On the other hand, it is now necessary to disagree with Cott when he states (1954, pp. 55-6): ' . . . a broad correlation has been established between cryptic coloration and relative palatability on the one hand, and between conspicuousness and deterrent attributes on the other. Such a relationship, supported by a great body of experimental and observational evidence.... is found among many groups of animals, including tectibranch molluscs (Garstang, I889-90).'

\section{Anomalous opisthobranchs}

The species investigated in the present work were selected solely on the grounds of availability; the conclusions arrived at are thus based on a number of opisthobranchs chosen more or less at random from the British fauna. Unfortunately, several species of nudibranchs, which appear to provide exceptions to my conclusions, were not available for study. The orange-red dorid Archidoris pseudoargus flammea and the supposedly cryptically coloured 
eolid Aeolidia papillosa are cases in point; going farther afield, the brilliantly marked chromodorid nudibranchs of warmer seas would clearly repay further study.

This work was done while I was the holder of a Leverhulme Fellowship in the University of Liverpool. I am indebted to Mr J. S. Colman for critical reading of the manuscript and for the provision of laboratory facilities. In addition, it is a pleasure to record my indebtedness to $\mathrm{Mr} \mathrm{D}$. Eggleston, Mr R. G. Hartnoll, Mr P. J. Miller and Mr K. Reddiah, for their help in collecting the material on which this paper is based. Mr D. Eggleston also kindly gave assistance in the gustatory tests. Dr A. K. Nagabhushanam gave guidance in the literature concerning the gut contents of fish.

\section{SUMMARY}

Feeding-acceptability tests with a variety of opisthobranchiate gastropods and marine aquarium fish gave rather uniform results; in such experiments, opisthobranchs were almost invariably refused as food by fish.

Descriptions are given of the glands which, placed often in the most vulnerable yet least vital regions of the body of the opisthobranch, are believed to produce deterrent secretions.

The results of these investigations are related to facts concerning the natural history of the animals concerned, and the conclusions reached are considered in the light of modern theories concerning the adaptive coloration of animals.

\section{REFERENCES}

ALDER, J. \& HANCOCK, A., I845-55. A monograph of the British nudibranchiate Mollusca. Ray Soc. Publ.

BarretT, J. H. \& Yonge, C. M., 1958. Collins Pocket Guide to the Sea Shore. 272 pp. London: Collins.

BAtesON, W., 1890. The sense-organs and perceptions of fishes; with remarks on the supply of bait. F. mar. biol. Ass. U.K., Vol. I, pp. 225-56.

Byne, L. St. G., I893. A contribution towards a list of the marine Mollusca of Teignmouth. F. Conchol., Vol. 7, pp. I75-88.

Сотт, H. B., 1940. Adaptive Coloration in Animals, 508 pp. London: Methuen.

- 1954. Allaesthetic selection and its evolutionary aspects. In Evolution as a Process. $367 \mathrm{pp}$. London: Allen and Unwin.

CrossLand, C., I9I I. Warning coloration in a nudibranch mollusc and in a chameleon. Proc. zool. Soc. Lond., Vol. 79, pp. 1062-7.

CROzIER, W. J., I9I7. The nature of the conical bodies on the mantle of certain nudibranchs. Nautilus, Vol. 30, pp. 103-6.

Eales, N. B., 1921. Aplysia. Mem. Lpool biol. Com., No. 24, 84 pp.

Eliot, C. N. E., I9Iо. A monograph of the British nudibranchiate Mollusca; suppl. vol. Ray Soc. Publ., pp. I-I98, pls. I-8.

ForD, E., I92I. A contribution to our knowledge of the life-histories of the dogfishes landed at Plymouth. F. mar. biol. Ass. U.K., Vol. 12, pp. 468-505. 
GARSTANG, W., I889. Report on the nudibranchiate Mollusca of Plymouth Sound. F. mar. biol. Ass. U.K., Vol. I, pp. 173-98.

— I890a. A complete list of the opisthobranchiate Mollusca found at Plymouth; with further observations on their morphology, colours, and natural history. F. mar. biol. Ass. U.K., Vol. I, pp. 399-457.

- I 8906 . Foreign substances attached to crabs. Nature, Lond., Vol. 4I, pp. 4I7, $490,538$.

Herdman, W. A. \& ClubB, J. A., I892. Third report upon the Nudibranchiata of the L.M.B.C. district. Proc. Lpool biol. Soc., Vol. 4, pp. I3I-69, pls. VI-IX.

Homans, R. E. S. \& NeEdler, A. W. H., 1944. Food of the haddock. Proc. Nova Scotia Inst. Sci., Vol. 21, pp. I-35.

Lemche, H., 1929. Gastropoda Opisthobranchiata. Zool. Faroes, no. 53, pp. I-35.

McMillan, N. F., r94I. Sea-anemones and nudibranchs. F. Conchol., Vol. 21, p. 282.

Pruvot-Fol, A., I954. Faune de France. Mollusques Opisthobranches, 460 pp. Paris: Lechevalier.

Steedman, H. F., 1950. Alcian blue 8GS : a new stain for mucin. Quart. F. micr. Sci., Vol. 9I, pp. 477-9.

ThOMpson, T. E., 1958. The natural history, embryology, larval biology and postlarval development of Adalaria proxima (Alder \& Hancock) (Gastropoda Opisthobranchia). Phil. Trans. B, Vol. 242, pp. I-58.

— 1960a. Defensive acid-secretion in marine gastropods. F. mar. biol. Ass. U.K., Vol. 39, pp. II5-22.

- $1960 b$. On a disputed feature of the anatomy of Dendronotus frondosus Ascanius. Proc. malacol. Soc. Lond., (in press).

Thompson, T. E. \& SlinN, D. J., 1959. On the biology of the opisthobranch Pleurobranchus membranaceus. F. mar. biol. Ass. U.K., Vol. 38, pp. 507-24.

TodD, R. A., 1903. Notes on the invertebrate fauna and fish-food of the bays between the Start and Exmouth. F. mar. biol. Ass. U.K., Vol. 6, pp. 54I-6I.

VERRILL, A. E., I873. Report upon the invertebrate animals of Vineyard Sound and the adjacent waters, with an account of the physical characters of the region. New England Fish. Rep. I871-2, U.S. Comm. Fish., pp. 295-778.

Wilson, D. P., 1937. Life of the Shore and Shallow Sea, I50 pp. London: Ivor Nicholson and Watson. 